Communication

\title{
Effective Synthesis of a Novel Tetrahydrofuran Containing Triterpenoid: $5^{\prime}(\mathrm{Z})$-Benzylidene- tetrahydrofurano[3,2-b]lup-20(29)-en-28-oate
}

\author{
Rinat Gubaidullin ${ }^{1, *}$, Darya Nedopekina ${ }^{1}{ }^{1}$, Regina Evstifeeva ${ }^{2}$ and Yurij Prochukhan ${ }^{2}$ \\ 1 Institute of Petrochemistry and Catalysis, Russian Academy of Sciences, 141 prosp. Oktyabrya, 450075 Ufa, \\ Russia; rawbe2007@mail.ru \\ 2 Bashkir State University, 32 Zaki Validi Str., 450076 Ufa, Russia; reginaevsti@mail.ru (R.E.); \\ dissovet2@rambler.ru (Y.P.) \\ * Correspondence: rinatg83@mail.ru; Tel.: +7-(917)-7636239
}

Received: 4 December 2018; Accepted: 27 December 2018; Published: 28 December 2018

check for updates

\begin{abstract}
The title compound 5'(Z)-benzylidene-tetrahydrofurano[3,2-b]lup-20(29)-en-28-oate was synthesized with high chemo-, regio-, and stereoselectivity by 5-exo-dig cycloisomerization of methyl $2 \alpha$-phenylpropynyl-3-oxolup-20(29)-en-28-oate with use of $\mathrm{KN}\left(\mathrm{SiMe}_{3}\right)_{2}$-DME. The novel betulinic acid derivative was fully characterized by conventional analytical methods and all proton and carbon signals have been completely assigned by 2D-NMR experiments.
\end{abstract}

Keywords: betulinic acid; alkynes; tetrahydrofuranes; 5-exo-dig heterocyclization

\section{Introduction}

The available plant metabolite, that is betulinic acid and its semi-synthetic derivatives, represent an important class of biologically active substances, which are in high demand in medicinal chemistry and pharmacological studies [1-4]. In the synthesis of numerous derivatives of betulinic acid, directed at enhancing its biological potential, particular emphasis is focused on the approaches aimed at constructing of various types of heterocyclic fragments at triterpenoid core [5]. The ketone carbonyl at C-3 of betulinic acid was utilized in syntheses of various fused heterocycles at the 2,3-position of the lupane skeleton including isoxazole, pyrazine, benzopyrazine, pyridine, indole, and pyrazole rings [5-9]. These triterpenoid derivatives modified with heterocyclic rings attached to the A-ring of the triterpene have shown antitumor, anti-inflammatory and leishmanicidal activities. In this group of heterocyclic ring-substituted triterpenoids, betulinic acid analogues containing furan or tetrahydrofuran rings are little-known compounds. At the same time, polysubstituted furans, tetrahydrofurans and their precursors, 2-alkylidenetetrahydrofurans, are present in numerous natural products or used as important synthetic building blocks in the synthesis of promising biologically active substances [10-13]. Recently, we developed an efficient method for the synthesis of 2-propargyl 3-oxo-triterpene acid derivatives [14]. The resulting triterpene compounds containing a 4-pentyn-1-one structural unit in ring A have been successfully used in the anionic 5-exo-dig cycloisomerization induced by a strong base, $\mathrm{KN}\left(\mathrm{SiMe}_{3}\right)_{2}$-DME [15]. The heterocyclization of these compounds also was performed in the presence of $\mathrm{Au}(\mathrm{I})^{+}$phosphine complexes [16]. In the continuation of our studies, this article describes the preparation of new $[3,2-b]$ tetrahydrofuran-fused lupane triterpenoid 6-That is, $5^{\prime}(Z)$-benzylidene-tetrahydrofurano [3,2-b]lup-20(29)-en-28-oate, by employing the 5-exo dig heterocyclization of accessible 2-phenylpropynyl derivative of betulinic acid. 


\section{Results}

In the synthesis of the target triterpenoid 6, C-2 propargyl derivative of betulinic acid 5 was used as the starting compound, which was obtained in several stages from betulin by the method previously developed by our research group [14] (Scheme 1). The key stage of the scheme was $\alpha$ alkylation with propargyl bromide of potassium enoxytriethylborate generated from methylbetulonate 2 under the action of $\mathrm{KN}\left(\mathrm{SiMe}_{3}\right)_{2}-\mathrm{Et}_{3} \mathrm{~B}$. Stereoselective reduction of the keto group in the propynyl derivative of betulonic acid 3 using $\mathrm{NaBH}_{4}$ modified with $\mathrm{CeCl}_{3}$, produced methylbetulinate 4 in good yield [14] (Scheme 1).
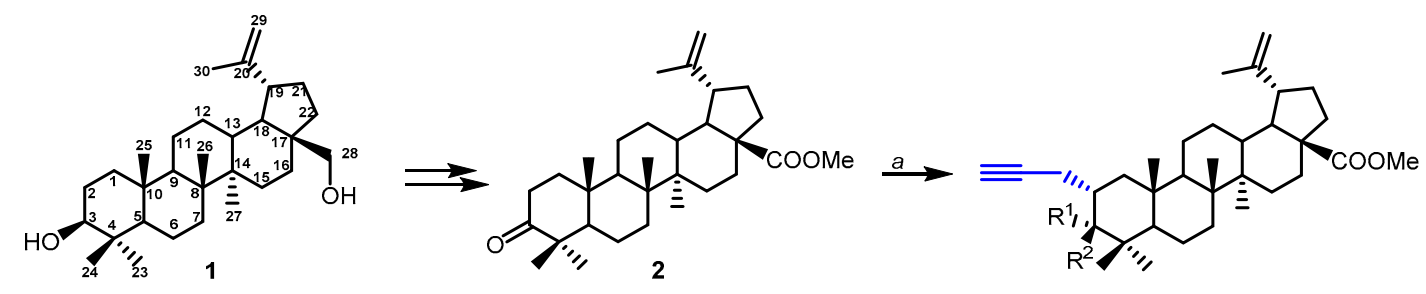

Reagents and conditions:

a, $\mathrm{KN}\left(\mathrm{SiMe}_{3}\right)_{2}-\mathrm{Et}_{3} \mathrm{~B}$, propargyl bromide, $\mathrm{DME}_{i}$

b, $\mathrm{NaBH}_{4}, \mathrm{CeCl}_{3} \cdot 7 \mathrm{H}_{2} \mathrm{O}, \mathrm{MeOH} / \mathrm{THF},-30^{\circ} \mathrm{C}$ to $20^{\circ} \mathrm{C}, \mathrm{Ar}, 2 \mathrm{~h}$;

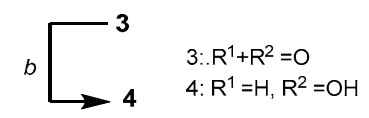

Scheme 1. Preparation of C-2 propargylbetulinic acid 4.

The starting compound 4 was transformed into triterpenoid 5 by Sonogashira cross-coupling in the presence of $\mathrm{PdCl}_{2}\left(\mathrm{PPh}_{3}\right)_{2}, \mathrm{CuI}$ and $\mathrm{Et}_{3} \mathrm{~N}$ (Scheme 2). Triterpenoid 5 heterocyclization was carried out under the action of $\mathrm{KN}\left(\mathrm{SiMe}_{3}\right)_{2}$ in DME. The reaction proceeded at room temperature and in a short period of time yielded a single product, that is target triterpenoid 6 , with a yield of $82 \%\left({ }^{1} \mathrm{H}\right.$ - and ${ }^{13} \mathrm{C}-\mathrm{NMR}$ spectra). It is interesting to note that only 5 -exo dig cyclization occurred and stereoisomerically pure compound (Z-5) was found. We did not detect pyran derivatives derived from 6-endo cyclization and stereoisomer (E-5) even in the trace amounts. Exocyclic enol ethers are known to easily undergo hydrolysis $[16,17]$. The triterpenoid 6 obtained by us showed protolytic stability during long-term storage ( 12 months) in an inert atmosphere at a temperature of $\pm 5^{\circ} \mathrm{C}$. However, it was easily hydrolyzed to give phenylaceton-3 $\beta$-hydroxylup-20(29)-en-28-oate 7 in chloroform-d within $6 \mathrm{~h}$, producing a mixture of compounds 6 and 7 in 60:40 ratio $\left({ }^{1} \mathrm{H}\right.$ - and $\left.{ }^{13} \mathrm{C}-\mathrm{NMR}\right)$. During the purification of triterpenoid 6 by the method of column chromatography on $\mathrm{SiO}_{2}$, an analytically pure sample of the compound was isolated in $32 \%$ yield along with its hydrolysis product, that is triterpenoid 7 in $51 \%$ yield.

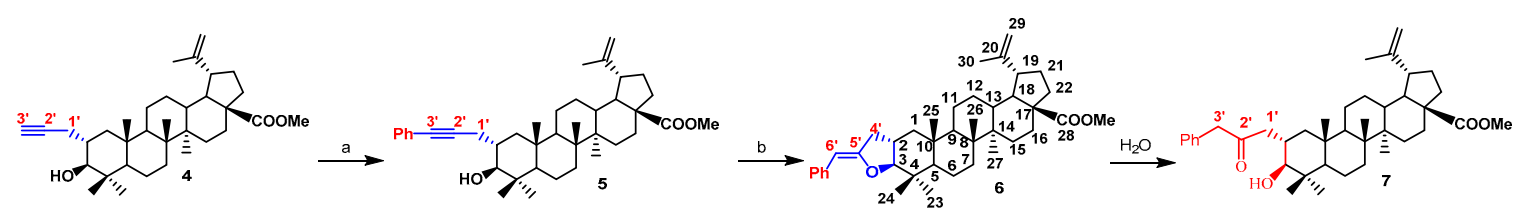

Reagents and conditions:

Reagents and conditions:
a, $\mathrm{Arl}, \mathrm{PdCl} \mathrm{l}_{2}\left(\mathrm{PPP}_{3}\right)_{2}, \mathrm{Cul}, \mathrm{Et} \mathrm{N}, \mathrm{DMF}, \mathrm{Ar}, 20^{\circ} \mathrm{C}$;
b, $\mathrm{KN}\left(\mathrm{SiMl}_{3}\right)_{2}, \mathrm{DME}, 20^{\circ} \mathrm{C}$.

Scheme 2. Synthesis of [3,2-b]tetrahydrofuran-fused betulinic acid.

The structure of the resulting compound was defined using one-dimensional $\left({ }^{1} \mathrm{H},{ }^{13} \mathrm{C}\right)$ and two-dimensional (COSY, NOESY, HSQC, HMBC) NMR spectroscopy.

The ${ }^{13} \mathrm{C}$-NMR spectrum of compound 6 , exhibited no signals for the acetylene group and the $3-\mathrm{OH}$ carbon atom, indicating that these functional groups in the initial compound 5 were involved in the intramolecular cyclization. Along with the characteristic signal of the quaternary carbon atom C-20 (150.6 ppm), a new signal of the quaternary carbon atom (DEPT, HSQC) was registered in the region of $151.3 \mathrm{ppm}$, which is related to the carbon atom $C-5^{\prime}$. The signals of carbon atoms $C-6^{\prime}$ and 
C-3 resonated in the range of 97.7 and $96.7 \mathrm{ppm}$. In the ${ }^{1} \mathrm{H}-\mathrm{NMR}$ spectrum, along with the proton signals at C-29, a new singlet signal of the vinylidene proton $\mathrm{H}-6^{\prime}$ was present in the region of 5.27 ppm. Methylene protons $\mathrm{H}-4^{\prime}$ resonated in the region of 2.66 and $2.41 \mathrm{ppm}$. The obtained spectral data allowed us to conclude that the structure of compound 6 contains a trisubstituted double bond and a tetrahydrofuran ring. The stereochemistry of Z-5 triterpenoid was defined applying two-dimensional NMR correlation spectra. In the ${ }^{1} \mathrm{H}-\mathrm{NOESY}$ spectrum of compound Z-5, there were cross-peaks between the signals of protons $\mathrm{H}-4^{\prime}, \mathrm{H}-6^{\prime}$ and $\mathrm{H}-2$.

\section{Materials and Methods}

The starting compounds and reagents were purchased from standard commercial suppliers and used without any further purification. Betulonic acid was obtained from betulin according to known procedures [18]. IR spectra were obtained with use of a Vertex 70v spectrometer (Bruker, Karlsruhe, Germany) (solutions in $\mathrm{CHCl}_{3}$ ). ${ }^{1} \mathrm{H}$ - and ${ }^{13} \mathrm{C}$-NMR spectra were recorded on a Bruker Avance-500 instrument $\left(500.13\left({ }^{1} \mathrm{H}\right)\right.$ and $\left.125.78 \mathrm{MHz}\left({ }^{13} \mathrm{C}\right)\right)$ or on a Bruker Avance-400 instrument $\left(400.13\left({ }^{1} \mathrm{H}\right)\right.$ and $\left.100.62 \mathrm{MHz}\left({ }^{13} \mathrm{C}\right)\right)$ in $\mathrm{CDCl}_{3}$ with $\mathrm{Me}_{4} \mathrm{Si}$ as the internal standard. Mass spectra of new compounds were recorded on an LCMS-2010 EV (Shimadzu, Kyoto, Japan) spectrometer of the UfIC RAS Center for Collective Use "Chemistry". Elemental analysis was carried out on a 1106 analyzer (Carlo Erba, Milan, Italy). TLC was carried out on Sorbfil plates (Sorbpolimer, Krasnodar, Russia) in hexane-EtOAc (from 10:1 to 2:1) or in $\mathrm{CHCl}_{3}-\mathrm{MeOH}$ (20:1); spots were visualized with anisaldehyde. Silica gel L (KSKG grade, $50-160 \mu \mathrm{m}$ ) was employed for column chromatography. Starting triterpenoid 4 was prepared as previously reported [15]. NMR spectra of all new compounds are in Supplementary Materials.

\subsection{2a-Phenylpropynyl-3ß-hydroxylup-20(29)-en-28-oate (5)}

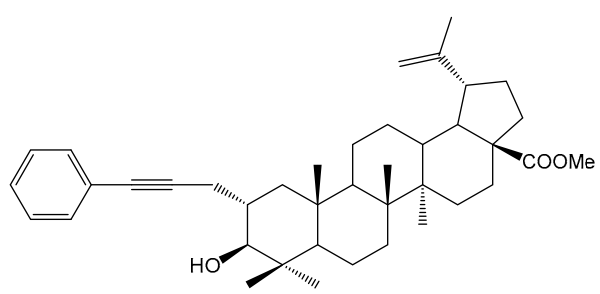

A mixture of triterpenoid 4 (102 mg, $0.2 \mathrm{mmol})$, iodobenzene $(0.019 \mathrm{~mL}, 0.17 \mathrm{mmol})$ and $\mathrm{Et}_{3} \mathrm{~N}$ $(0.23 \mathrm{~mL}, 1.64 \mathrm{mmol})$ were dissolved in DMF $(3.0 \mathrm{~mL})$. Then $\mathrm{CuI}(3.8 \mathrm{mg}, 0.02 \mathrm{mmol})$ and $\mathrm{PdCl}_{2}\left(\mathrm{PPh}_{3}\right)_{2}$ $(5.6 \mathrm{mg}, 0.01 \mathrm{mmol}$ ) were added to the mixture simultaneously and the resulting mixture was stirred at room temperature for $1.5 \mathrm{~h}$ under an argon atmosphere. The completion of reaction was monitored by TLC analysis. The reaction was quenched by addition of water and extracted with $\mathrm{CHCl}_{3}(3 \times 10 \mathrm{~mL})$. The combined organic extracts were dried with $\mathrm{MgSO}_{4}$ and concentrated under reduced pressure. The residue was purified by column chromatography on $\mathrm{SiO}_{2}$ with hexane/EtOAc (15:1) as an eluent to afford pure product 5 as a white powder ( $99 \mathrm{mg}, 0.17 \mathrm{mmol}, 85 \%)$. Rf: 0.15 (10:1 hexan:EtOAc). IR $\left(\mathrm{CHCl}_{3}\right): 3467(\mathrm{OH}), 1726(\mathrm{C}=\mathrm{O}) \mathrm{cm}^{-1}$. m.p. $122-125^{\circ} \mathrm{C} .{ }^{1} \mathrm{H}-\mathrm{NMR}\left(\delta, \mathrm{ppm}, \mathrm{CDCl}_{3}, 400 \mathrm{MHz}\right): 7.43$ $(2 \mathrm{H}, \mathrm{m}$, arom $), 7.30(3 \mathrm{H}, \mathrm{m}$ arom $), 4.75,4.61(2 \mathrm{H}$, both br s, H-29), $3.69(3 \mathrm{H}, \mathrm{s}, \mathrm{COOMe}), 3.05(1 \mathrm{H}, \mathrm{d}$, $J=10.4 \mathrm{~Hz}, \mathrm{H}-3), 3.03(1 \mathrm{H}, \mathrm{m}, \mathrm{H}-19), 2.65\left(1 \mathrm{H}, \mathrm{dd}, J=16.8,4.0 \mathrm{~Hz}, \mathrm{H}^{\mathrm{a}}-\mathrm{1}^{\prime}\right), 2.50(1 \mathrm{H}, \mathrm{dd}, J=16.8,6.4 \mathrm{~Hz}$, $\left.\mathrm{H}^{\mathrm{b}}-1^{\prime}\right), 2.29-0.86\left(22 \mathrm{H}, \mathrm{m}, \mathrm{CH}, \mathrm{CH}_{2}\right.$ in pentacyclic sceleton and $\left.2 \mathrm{H}, \mathrm{H}^{\mathrm{a}}-1, \mathrm{H}^{\mathrm{b}}-1\right), 1.7(3 \mathrm{H}, \mathrm{s}, \mathrm{H}-30), 1.02$, 0.99, 0.95, 0.90, 0.82 (3H each, all s, H-23-H-27), $0.77(1 \mathrm{H}, \mathrm{d}, J=9.2 \mathrm{~Hz}, \mathrm{H}-5) .{ }^{13} \mathrm{C}-\mathrm{NMR}\left(\delta, \mathrm{ppm}, \mathrm{CDCl}_{3}\right.$, $100 \mathrm{MHz}$ ): 176.8 (C-28), 150.5 (C-20), 131.7, 128.2, 127.6, 124.0 (arom), 109.6 (C-29), 88.7 (C-2'), 82.2 (C-3'), 81.8 (C-3), 56.6 (C-5), 55.5 (C-17), 51.3 (COOMe), 50.5 (C-9), 49.5 (C-18), 47 (C-19), 45.2 (C-1), 42.5 (C-14), 40.7 (C-8), 39.2 (C-10), 38.3 (C-13), 37.5 (C-4), 36.9 (C-22), 35.5 (C-2), 34.3 (C-7), 32.2 (C-16), 30.6 (C-21), 29.7 (C-15), 28.4 (C-24), 25.5 (C-12), 23.5 (C-1'), 20.9 (C-11), 19.4 (C-30), 18.3 (C-6), 16.9 (C-26), 16.3 (C-23), 15.9 (C-25), 14.8 (C-27). Anal. Calcd for $\mathrm{C}_{40} \mathrm{H}_{56} \mathrm{O}_{3}$ : C, 82.14; H, 9.65. Found: $\mathrm{C}, 81.99 ; \mathrm{H}$, 9.67. MS (APCI): $m / z[\mathrm{M}+\mathrm{H}]^{+}$, calcd for $\mathrm{C}_{40} \mathrm{H}_{56} \mathrm{O}_{3}$ : 585.43; found: 585.5. 


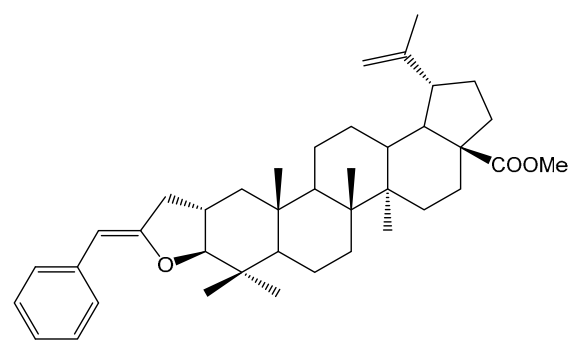

A $1 \mathrm{M}$ solution of $\mathrm{KN}\left(\mathrm{SiMe}_{3}\right)_{2}(0.26 \mathrm{~mL}, 0.26 \mathrm{mmol})$ in THF was added to a solution of triterpenoid $5(117 \mathrm{mg}, 0.2 \mathrm{mmol})$ in DME $(2.8 \mathrm{~mL})$. The reaction mixture was stirred at room temperature under an argon atmosphere. The completion of reaction was monitored by TLC analysis. After $30 \mathrm{~min}$ reaction mixture was neutralized with saturated aqueous solution of $\mathrm{NH}_{4} \mathrm{Cl}(\mathrm{aq})$. The product was extracted with EtOAc $(3 \times 10 \mathrm{~mL})$. The combined extracts were dried with $\mathrm{MgSO}_{4}$ and concentrated. The residue was purified by column chromatography on $\mathrm{SiO}_{2}$ with hexane/EtOAc (30:1) as an eluent to give the appropriate compound 6 as a white powder $(37 \mathrm{mg}, 0.064 \mathrm{mmol}, 32 \%)$ and 7 as a white powder $(61 \mathrm{mg}$, $0.10 \mathrm{mmol}, 51 \%)$. Rf: 0.53 (10:1 hexan:EtOAc). IR $\left(\mathrm{CHCl}_{3}\right): 1725(\mathrm{C}=\mathrm{O}), 1674(\mathrm{C}=\mathrm{C}) \mathrm{cm}^{-1}$. m.p. 140-143 ${ }^{\circ} \mathrm{C} .{ }^{1} \mathrm{H}-\mathrm{NMR}\left(\delta, \mathrm{ppm}, \mathrm{CDCl}_{3}, 400 \mathrm{MHz}\right): 7.57(1 \mathrm{H}, \mathrm{d}, J=7.6 \mathrm{~Hz}$, arom), $7.28(3 \mathrm{H}, \mathrm{m}$, arom $), 7.09(1 \mathrm{H}, \mathrm{t}$, $J=7.6 \mathrm{~Hz}$, arom $), 5.27\left(1 \mathrm{H}, \mathrm{s}, \mathrm{H}-6^{\prime}\right), 4.77,4.64(2 \mathrm{H}$, both br s, H-29), $3.7(3 \mathrm{H}, \mathrm{s}, \mathrm{COOMe}), 3.41(1 \mathrm{H}, \mathrm{d}$, $J=10.8 \mathrm{~Hz}, \mathrm{H}-3), 3.02(1 \mathrm{H}, \mathrm{m}, \mathrm{H}-19), 2.66\left(1 \mathrm{H}, \mathrm{dd}, J=14.8,6.4 \mathrm{~Hz}, \mathrm{H}^{\mathrm{a}}-4^{\prime}\right), 2.41\left(1 \mathrm{H}, \mathrm{t}, J=12.8 \mathrm{~Hz}, \mathrm{H}^{\mathrm{b}}-4^{\prime}\right)$, 2.29-0.86 $\left(22 \mathrm{H}, \mathrm{m}, \mathrm{CH}, \mathrm{CH}_{2}\right.$ in pentacyclic sceleton and $\left.2 \mathrm{H}, \mathrm{H}^{\mathrm{a}}-1, \mathrm{H}^{\mathrm{b}}-1\right), 2.07(1 \mathrm{H}, \mathrm{m}, \mathrm{H}-2), 1.72(3 \mathrm{H}, \mathrm{s}$, $\mathrm{H}-30), 1.18,1.01,0.97,0.94,0.93$ (3H each, all s, H-23-H-27). ${ }^{13} \mathrm{C}-\mathrm{NMR}\left(\delta, \mathrm{ppm}, \mathrm{CDCl}_{3}, 100 \mathrm{MHz}\right.$ ): 176.6 (C-28), 157.3 (C-5'), 150.5 (C-20), 137.2, 128.1, 127.2, 124.4 (arom), 109.6 (C-29), 97.7 (C-6'), 95.6 (C-3), 56.5 (C-17), 56 (C-5), 51.3 (COOMe), 50.6 (C-9), 49.5 (C-18), 47 (C-19), 42.5 (C-1), 42.5 (C-14), 41.1 (C-8), 39.6 (C-10), 38.2 (C-13), 37.9 (C-4'), 37.5 (C-4), 36.9 (C-22), 34.5 (C-7), 34.1 (C-2), 32.2 (C-16), 30.6 (C-21), 29.7 (C-15), 28.6 (C-23), 25.5 (C-12), 21.0 (C-11), 19.4 (C-30), 17.8 (C-6), 17.3 (C-26), 16.2 (C-25), 15.7 (C-24), 14.7 (C-27). Anal. Calcd for $\mathrm{C}_{40} \mathrm{H}_{56} \mathrm{O}_{3}: \mathrm{C}, 82.14 ; \mathrm{H}, 9.65$. Found: C, 81.94; H, 9.67. MS (APCI): $m / z[\mathrm{M}+\mathrm{H}]^{+}$, calcd for $\mathrm{C}_{40} \mathrm{H}_{56} \mathrm{O}_{3}$ : 585.43; found: 585.5.

\subsection{2a-Phenylaceton-3 $\beta$-hydroxylup-20(29)en-28-oate (7)}

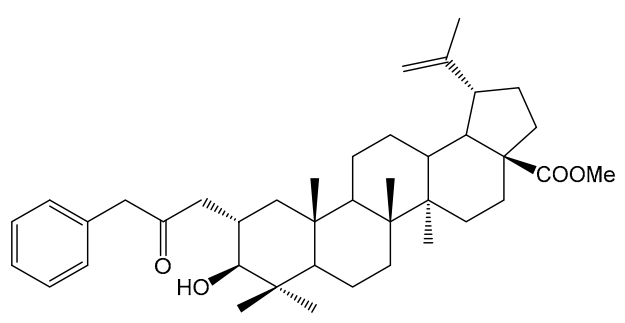

Rf: 0.11 (10:1 hexan:EtOAc). IR ( $\left.\mathrm{CHCl}_{3}\right): 3468(\mathrm{OH}), 1725(\mathrm{C}=\mathrm{O}) \mathrm{cm}^{-1}$. m.p. $97-98^{\circ} \mathrm{C} .{ }^{1} \mathrm{H}-\mathrm{NMR}(\delta$, ppm, $\left.\mathrm{CDCl}_{3}, 400 \mathrm{MHz}\right): 7.35-7.2(5 \mathrm{H}, \mathrm{m}$, arom $), 4.75,4.62$ (2H, both brs, H-29), $3.73\left(2 \mathrm{H}, \mathrm{s}, \mathrm{H}-3^{\prime}\right), 3.68$ $(3 \mathrm{H}, \mathrm{s}, \mathrm{COOMe}), 3.01(1 \mathrm{H}, \mathrm{m}, \mathrm{H}-19), 2.75\left(2 \mathrm{H}, \mathrm{m}, \mathrm{H}-3, \mathrm{H}-1^{\prime}\right), 2.27-0.82\left(22 \mathrm{H}, \mathrm{m}, \mathrm{CH}, \mathrm{CH}_{2}\right.$ in pentacyclic skeleton and $\left.3 \mathrm{H}, \mathrm{H}^{\mathrm{b}}-1^{\prime}, \mathrm{H}^{\mathrm{a}}-1\right), 1.72(3 \mathrm{H}, \mathrm{s}, \mathrm{H}-30), 0.96,0.95,0.91,0.85,0.77$ (3H each, alls, H-23-H-27), $0.68\left(1 \mathrm{H}, \mathrm{d}, J=9.2 \mathrm{~Hz}, \mathrm{H}^{\mathrm{a}}-5\right), 0.58\left(1 \mathrm{H}, \mathrm{m}, \mathrm{H}^{\mathrm{b}}-1\right) .{ }^{13} \mathrm{C}-\mathrm{NMR}\left(\delta, \mathrm{ppm}, \mathrm{CDCl}_{3}, 100 \mathrm{MHz}\right): 209.9\left(\mathrm{C}-2^{\prime}\right)$, 176.6 (C-28), 150.5 (C-20), 134.2, 129.5, 128.6, 126.9 (arom), 109.6 (C-29), 83.8 (C-3), 56.5 (C-17), 55.6 (C-5), 51.3 (COOMe), 50.6 (C-9), 50.5 (C-3'), 49.5 (C-18), 47.4 (C-1'), 46.9 (C-19), 46.4 (C-1), 42.4 (C-14), 40.7 (C-8), 39.4 (C-10), 38.3 (C-13), 37.5 (C-4), 36.9 (C-22), 34.3 (C-7), 32.3 (C-16), 32.2 (C-2), 30.6 (C-21), 29.6 (C-15), 28.2 (C-24), 25.5 (C-12), 20.9 (C-11), 19.4 (C-30), 18.5 (C-6), 16.7 (C-26), 15.9 (C-23), 15.9 (C-25), 14.7 (C-27). Anal. Calcd for $\mathrm{C}_{40} \mathrm{H}_{56} \mathrm{O}_{3}$ : C, 79.69; H, 9.70. Found: C, 79.45; H, 9.68. MS (APCI): $m / z[\mathrm{M}-\mathrm{H}]^{-}$, calcd for $\mathrm{C}_{40} \mathrm{H}_{58} \mathrm{O}_{4}$ : 601.43; found: 601.5 . 


\section{Conclusions}

Thus, we have presented an economical and chemoselective scheme for production of new 2-alkylidenetetrahydrofuran-fused pentacyclic triterpenoid using a base promoted 5-exo-dig cycloisomerization of 2-alkynyl derivative of betulinic acid.

Supplementary Materials: The supplementary materials are available online.

Author Contributions: R.E. did the synthesis; D.N. analyzed all data; R.G. prepared the manuscript; Y.P. edited and revised the manuscript.

Funding: This research was funded by the Russian Foundation for Basic Research (project no. 16-33-60008).

Conflicts of Interest: The authors declare no conflict of interest.

\section{References}

1. Cichewicz, R.H.; Kouzi, S.A. Chemistry, biological activity, and chemotherapeutic potential of betulinic acid for the prevention and treatment of cancer and HIV infection. Med. Res. Rev. 2004, 24, 90-114. [CrossRef] [PubMed]

2. Sarek, J.; Kvasnica, M.; Vlk, M.; Urban, M.; Dzubak, P.; Hajduch, M. The Potential of Triterpenoids in the Treatment of Melanoma. In Research on Melanoma-A Glimpse into Current Directions and Future Trends; Kvasnica, M., Ed.; InTech: Rijeka, Croatia, 2011; Volume 7, pp. 125-158.

3. Mukherjee, R.; Kumar, V.; Srivastava, S.K.; Agarwal, S.K.; Burman, A.C. Betulinic acid derivatives as anticancer agents: Structure activity relationship. Anticancer Agents: Med. Chem. 2006, 6, 271-279. [CrossRef]

4. Csuk, R. Betulinic acid and its derivatives: A patent review (2008-2013). Expert Opin. Ther. Pat. 2014, 24, 913-923. [CrossRef] [PubMed]

5. Kvasnica, M.; Urban, M.; Dickinson, N.J.; Sarek, J. Pentacyclic triterpenoids with nitrogen- and sulfur-containing heterocycles: Synthesis and medicinal significance. Nat. Prod. Rep. 2015, 32, 1303-1330. [CrossRef] [PubMed]

6. Laavola, M.; Haavikko, R.; Hämäläinen, M.; Leppänen, T.; Nieminen, R.; Alakurtti, S.; Moreira, V.M.; Yli-Kauhaluoma, J.; Moilanen, E. Betulin Derivatives Effectively Suppress Inflammation in Vitro and in Vivo. J. Nat. Prod. 2016, 79, 274-280. [CrossRef] [PubMed]

7. Haavikko, R.; Nasereddin, A.; Sacerdoti-Sierra, N.; Kopelyanskiy, D.; Alakurtti, S.; Tikka, M.; Jaffe, C.L.; Yli-Kauhaluoma, J. Heterocycle-fused lupane triterpenoids inhibit Leishmania donovani amastigotes. Medchemcomm 2014, 5, 445-451. [CrossRef]

8. Kumar, V.; Rani, N.; Aggarwal, P.; Sanna, V.K.; Singh, A.T.; Jaggi, M.; Joshi, N.; Sharma, P.K.; Irchhaiya, R.; Burman, A.C. Synthesis and cytotoxic activity of heterocyclic ring-substituted betulinic acid derivatives. Bioorganic Med. Chem. Lett. 2008, 18, 5058-5062. [CrossRef] [PubMed]

9. Urban, M.; Sarek, J.; Kvasnica, M.; Tislerova, I.; Hajduch, M. Triterpenoid Pyrazines and Benzopyrazines With Cytotoxic Activity. J. Nat. Prod. 2007, 70, 526-532. [CrossRef] [PubMed]

10. Bellur, E.; Freifeld, I.; Böttcher, D.; Bornscheuer, U.T.; Langer, P. Synthesis of (tetrahydrofuran-2-yl)acetates based on a 'cyclization/hydrogenation/enzymatic kinetic resolution' strategy. Tetrahedron 2006, 62, 7132-7139. [CrossRef]

11. Bellur, E.; Langer, P. Synthesis of Functionalized 2-Alkylidene-tetrahydrofurans Based on a [3+2] Cyclization/Bromination/Palladium(0) Cross-Coupling Strategy. Eur. J. Org. Chem. 2005, 2005, 4815-4828. [CrossRef]

12. Zeiss, H.J. Recent advances in the stereoselective synthesis of L-phosphinothricin. Pestic. Sci. 1994, 41, 269-277. [CrossRef]

13. Lorente, A.; Lamariano-Merketegi, J.; Albericio, F.; Álvarez, M. Tetrahydrofuran-Containing Macrolides: A Fascinating Gift from the Deep Sea. Chem. Rev. 2013, 113, 4567-4610. [CrossRef] [PubMed]

14. Gubaidullin, R.R.; Khalitova, R.R.; Galimshina, Z.R.; Spivak, A.Y. Synthesis of novel [3,2-b] furan-fused pentacyclic triterpenoids via gold-Catalyzed intramolecular heterocyclization of 2-alkynyl-3-oxotriterpene acids. Tetrahedron 2018. [CrossRef] 
15. Spivak, A.Y.; Gubaidullin, R.R.; Galimshina, Z.R.; Nedopekina, D.A.; Odinokov, V.N. Effective synthesis of novel C(2)-propargyl derivatives of betulinic and ursolic acids and their conjugation with $\beta$-D-glucopyranoside azides via click chemistry. Tetrahedron 2016, 72. [CrossRef]

16. Luo, F.T.; Schreuder, I.; Wang, R.T. Intramolecular oxypalladation and cross-coupling of acetylenic alkoxides. J. Org. Chem. 1992, 57, 2213-2215. [CrossRef]

17. Riediker, M.; Schwartz, J. Mercury(II)-induced cyclization of acetylenic alcohols: A new route to enol ethers and substituted enol ethers. J. Am. Chem. Soc. 1982, 104, 5842-5844. [CrossRef]

18. Kim, D.S.H.L.; Chen, Z.; Nguyen, v.T.; Pezzuto, J.M.; Qiu, S.; Lu, Z.Z. A Concise Semi-Synthetic Approach to Betulinic Acid from Betulin. Synth. Commun. 1997, 27, 1607-1612. [CrossRef]

2018 by the authors. Licensee MDPI, Basel, Switzerland. This article is an open access article distributed under the terms and conditions of the Creative Commons Attribution (CC BY) license (http://creativecommons.org/licenses/by/4.0/). 